
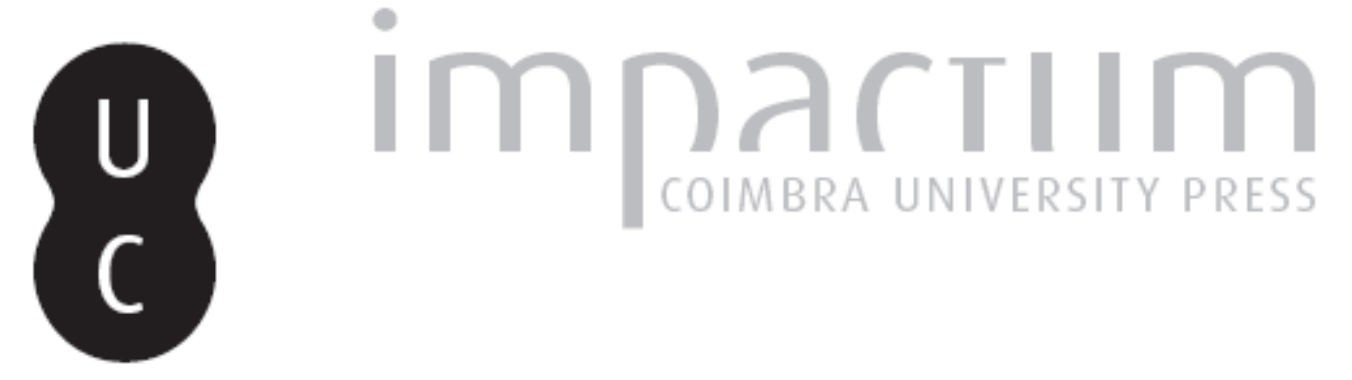

\title{
[Recensão a] Malcolm Schofield, Plato. Political Philosophy [Founders of Modern Political and Social Thought]
}

\author{
Autor(es): $\quad$ Schorn, Stefan \\ Publicado por: Imprensa da Universidade de Coimbra \\ URL \\ persistente: \\ URI:http://hdl.handle.net/10316.2/42212 \\ DOI: \\ DOI:https://doi.org/10.14195/2183-4105_8_6
}

Accessed : $\quad$ 26-Apr-2023 15:40:16

A navegação consulta e descarregamento dos títulos inseridos nas Bibliotecas Digitais UC Digitalis, UC Pombalina e UC Impactum, pressupõem a aceitação plena e sem reservas dos Termos e Condições de Uso destas Bibliotecas Digitais, disponíveis em https://digitalis.uc.pt/pt-pt/termos.

Conforme exposto nos referidos Termos e Condições de Uso, o descarregamento de títulos de acesso restrito requer uma licença válida de autorização devendo o utilizador aceder ao(s) documento(s) a partir de um endereço de IP da instituição detentora da supramencionada licença.

Ao utilizador é apenas permitido o descarregamento para uso pessoal, pelo que o emprego do(s) título(s) descarregado(s) para outro fim, designadamente comercial, carece de autorização do respetivo autor ou editor da obra.

Na medida em que todas as obras da UC Digitalis se encontram protegidas pelo Código do Direito de Autor e Direitos Conexos e demais legislação aplicável, toda a cópia, parcial ou total, deste documento, nos casos em que é legalmente admitida, deverá conter ou fazer-se acompanhar por este aviso.

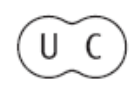




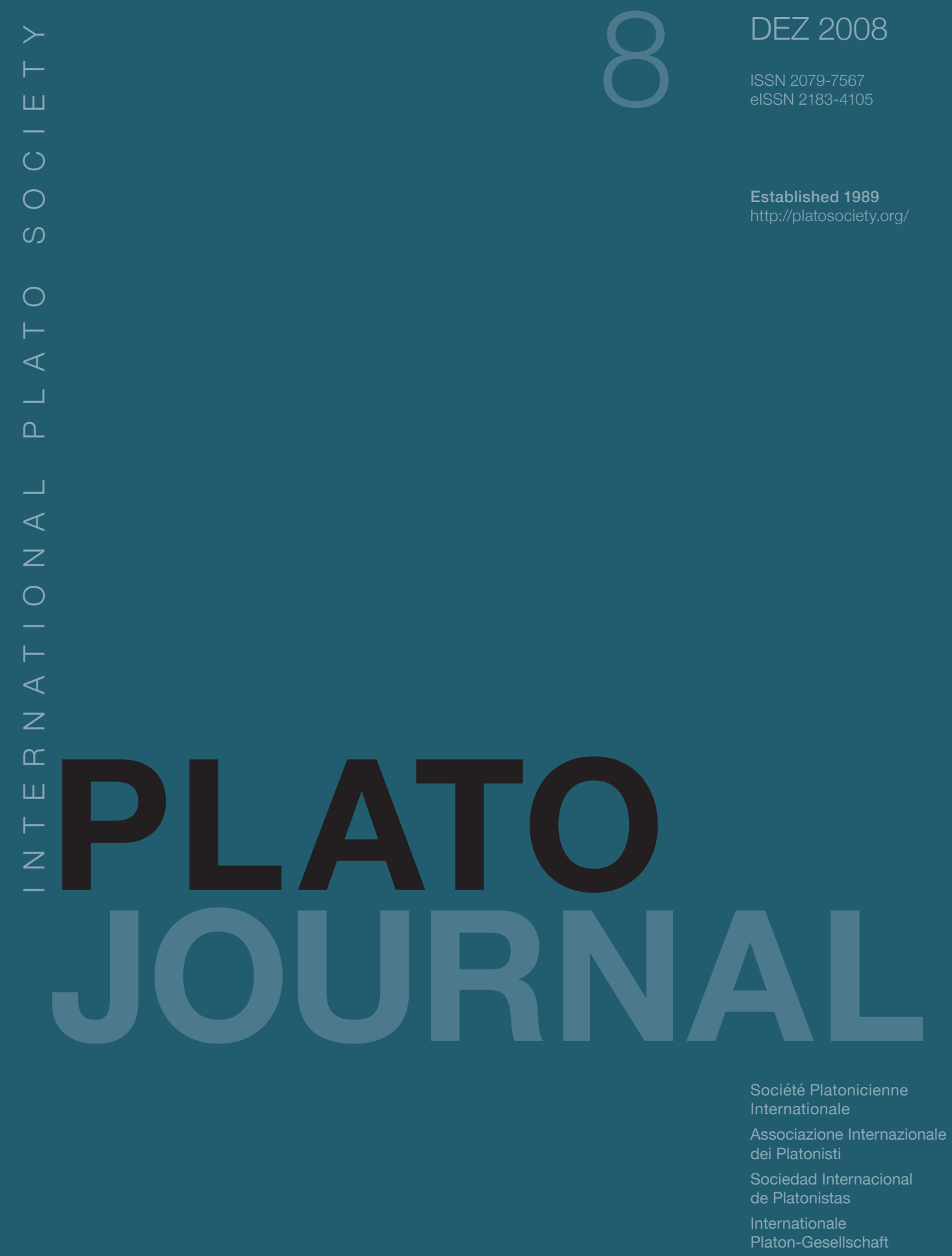




\section{Malcolm Schofield, Plato. Political Philosophy [Founders of Modern Political and Social Thought], Oxford: University Press 2006. ISBN 0-19- 924961-X. VIII+384 S.}

Die Reihe „Founders of Modern Political and Social Thought“, herausgegeben von Mark Philip, ist mit Malcolm Schofields (S.) Band zu Platon um eine ausgezeichnete Darstellung bereichert worden.

Das erste Kapitel, „The Republic: Context and Projects“ (7-50), erklärt Auswahl und Präsentation des Materials. Der Schwerpunkt von S.s Darstellung liegt auf der Politeia, was gut begründet ist. Dies ist der Dialog, der Platons eindrucksvollste Ideen im Bereich der politischen Philosophie enthält. Der Autor selbst scheint ihm den ersten Rang unter den Schriften zur politischen Philosophie eingeräumt zu haben, da spätere Dialoge Ideen weiterverarbeiten, die von dort inspiriert sind, und dort selbst einige Schlüsselthemen früherer Dialoge ihre abschließende Behandlung erfahren. Auch für spätere Autoren bis in die Neuzeit war dieser Dialog der wichtigste Referenztext. Nichtsdestotrotz geht $S$. durchgehend auf die Nomoi sowie häufig auf den Politikos und andere Dialoge ein und verdeutlicht so, wie die in der Politeia entworfene Konzeption im Kontext von Platons (nicht nur) politischer Philosophie als Ganzer zu bewerten ist.

S. diskutiert zunächst den biographischen Hintergrund der Politeia. Den 7. Brief hält er hierbei für unecht. Wichtigstes Argument ist, daß Platon dort in der ersten Person („ich war gezwungen zu sagen“, 326a) auf die Politeia (499b) verweist. Dies bedeute entweder, daß Platon dort in Sokrates sein Sprachrohr gesehen habe oder auf die Politeia nicht als einen Dialog, sondern als eine Äußerung in eigener Person verweise. Anders als andere Verfechter der Unechtheit, welche die Angaben des Briefes dennoch als wertvoll für Platons Philosophie und geistige Entwicklung ansehen, betont er Widersprüche zu Apologie und Kriton.

Von besonderem Interesse ist S.s Verortung der Politeia im Kontext der vorangehenden und gleichzeitigen Politeia-Literatur. Er betont zu Recht, daß diese bis dato politische Streitschriften mit deutlich prospartanischer Tendenz waren, was beim Zielpublikum Platons Erwartungen auslöste, die dann durch deutliche Kritik an spartanischen Einstellungen und Institutionen sowie Darlegungen darüber, daß und wie man darüber hinauskommen muß, enttäuscht

PLATO, The electronic Journal of the International Plato Society, n 8, 2008.

http://gramata.univ-paris1.fr/Plato

(c) All rights of reproduction of any form reserved. 
und provoziert wurden. In den Nomoi sollte später diese Kritik noch expliziter sein. Die Frage, ob Erziehung für Platon ein ethisches oder politisches Thema ist, beantwortet S. zu Recht mit: beides, sowohl in der Politeia als auch in den Nomoi (35-43).

Das Kapitel „Athens, Democracy and Freedom“ (51-99) betrachtet Platon im Kontext der athenischen Demokratie. S. adaptiert die terminologische Differenzierung des Politologen Michael Walzer, der zwischen „immanent or connected and rejectionist or disconnected critique“ differenziert, „criticism working from a position within or detached from a society, and with or against the system in question”. Seine These ist, daß Platons Komplexität daher rührt, daß er in beiden Weisen schreibt, bisweilen sogar gleichzeitig (54). S. wendet sich gegen Julia Annas Ansicht, Platon habe in späterer Zeit, im Politikos und den Nomoi, seine ursprünglich strikt negative Meinung von Demokratie relativiert und eine positive Ansicht fixierten Rechts entwickelt, folgt aber auch nicht uneingeschränkt Christopher Rowe, der gegen eine grundsätzliche Änderung in Platons Einstellung plädiert. Er betont, daß es Platon nie um Verfassungen an sich ankommt, sondern seine Dialoge charakterisiert sind durch „a constant preoccupation with the need for wisdom or expertise in government, a vision of what constitutes a true community, and ongoing engagement with the challenge of developing an ideology which will secure the commitment of citizens to a social and political order which will embody reason and genuine community" (62). S. untersucht die Verbindung von Demokratie und Rhetorik, wie sie v.a. im Gorgias zum Ausdruck kommt, zeigt die Bedeutung von Schmeichelei in diesem Zusammenhang auf und analysiert textnah, wie sich Platon dort gegen Thukydides' These wendet, nach der die athenische Demokratie erst nach Perikles degeneriert sei. In den Nomoi, so S., entwickelt der Fremde aus Athen eine Solonfigur - eine ideale Verfassung, für die „moderate Freiheit“ kennzeichnend ist. Diese besteht in "voluntary acceptance of the rule of laws“ und „the freedom of participation in the political system that citizens must enjoy if they are to be proper citizens, and not simply the slaves of their rulers" (80). Daß hier, anders als in der Politeia, eine Form von Freiheit betont wird, liegt für $S$. nicht an einer grundsätzlichen Meinungsänderung, sondern ist bedingt durch das dialogische Register der Nomoi. In den Nomoi spricht Platon anders als in der Politeia zu seinem Publikum in einer Form, die dessen Erfahrungshorizont angepaßt ist (81).

PLATO, The electronic Journal of the International Plato Society, n 8, 2008.

http://gramata.univ-paris1.fr/Plato

(c) All rights of reproduction of any form reserved. 
Kapitel 3, „Problematizing Democracy“ (100-135) analysiert vor allem Platons einzige explizite Behandlung der Demokratie, die in Buch 8 der Politeia zu finden ist. Während diese oft von der Forschung als wirklichkeitsfremde Karikatur angesehen wird, sieht $S$. hier eine theoretische Abhandlung in Form einer Satire. Platon gesteht der Demokratie zu, daß unter ihr Gleichheit und Freiheit florieren, allerdings nicht rationale Freiheit, die Platon befürwortet, sondern Freiheit zu tun, was man will (108). Ausgangspunkt für Platons Ablehnung der Demokratie ist ihr Potential zur Anarchie.

Das 4. Kap. ist der zentralen Frage nach dem Verhältnis von Herrschaft und Wissen gewidmet („The Rule of Knowledge“) (136-193). Wie S. darlegt (137), scheinen sich in Platons Schriften zwei Antworten darauf finden zu lassen: „One is the idea of a specifically political expertise, managing the knowledge and skills of other experts. The other is the idea of philosophical wisdom, particularly moral wisdom." Das heißt: Politikos und Politeia. Nachdem S. in diesem Kontext die Interpretationen von John Stuart Mill und Benjamin Jowett diskutiert hat, bespricht er die Rolle des politischen Wissens im Charmides und im Euthydemos, die als erste Dialoge für dieses Problem von Relevanz sind: „How might politics become a domain where knowledge rules? This is the underlying question, I suggest, fuelling Plato's interest in the idea of architectonic knowledge that is explored in the Charmides and the Euthydemus." (155). S. geht dann zur Politeia über, in der die Herrschaft des Wissens eine zentrale Rolle spielt. Das Paradoxon des Philosophen-Königs-Satzes besteht darin, daß Philosophen gewöhnlich realitätsfremde Gestalten sind. Ein Wissenskonzept wie das des "Architektenwissens“ („architectonic knowledge“, vgl. 144-145) im Politikos (259e-260c) würde eine Lösungsmöglichkeit des Paradoxon darstellen, doch betont S. gegen Charles Kahn, daß es in der Politeia nichts gibt, was diesem gleicht (156-157). Da aber die gewohnte politische Ordnung nicht mehr existiert und der platonische Staat in der richtigen Weise organisiert ist, verliert die Idee eines Philosophen-Königs mit philosophischem Wissen an Absurdität (159): „The Republic's philosopher ruler is therefore no political manager or ,scientific governor' on the model desired by John Stuart Mill. Plato is imagining something quite different. He is considering what society would be like if its values were shaped by a Socrates, and then embedded as an overriding respect for knowledge and virtue in the structures and institutions of the city" (164).

PLATO, The electronic Journal of the International Plato Society, n 8, 2008.

http://gramata.univ-paris1.fr/Plato

(c) All rights of reproduction of any form reserved. 
„Architektenwissen“ ist das Thema des Politikos. Dort wird angenommen, daß der Staatsmann sein politisches Expertenwissen praktiziert im Hinblick auf das Gute, Edle und Gerechte, verstanden als unabhängige Tugenden (164). „The old idea of the king as shepherd of his flock is successively defended, criticized and then abandoned for a new model: the statesman as weaver" (165). Dennoch empfiehlt Platon dem Leser nicht unzweideutig, daß die Anwendung politischen "Architektenwissens“ das Idealrezept für eine florierende menschliche Gesellschaft darstellt. S. sieht ein Problem im Abstraktheitsgrad des Entwurfes: "How someone might acquire political knowledge is never discussed, nor what education would be appropriate for someone who is to acquire it. Nor is there any treatment or even mention of the moral character of the person who is imagined as possessing it. The Statesman develops a complex account of political knowledge. But that account is sparer and more purely hypothetical than the project of the Republic (or the Laws)." (174) Anders als in der Politeia und den Nomoi wird nicht gefragt, wie die Gesellschaft organisiert sein muß, allein das Wissen des Politikers zählt. Während der Philosoph in der Politeia nur ungern die Herrschaft übernähme, scheint der "political manager" (178), der nicht mit dem Philosophen identifiziert wird, damit kein Problem zu haben. Die Frage, ob Platon im Staatsmann des Politikos den Philosophen der Politeia sieht, beantwortet er mit einem Zitat von Melissa Lane mit „Jein“: ,Yes,' in the sense that the statesman does have to share in at least the most important part of the philosophers' knowledge. ... But ,No,' in the sense that the Statesman precisely defines the statesman ... by his knowledge of ruling and whose relationship to ruling therefore differs from that of the pure philosopher..." (180).

Kap. 5, "Utopia” (194-249) ist Platons Gesellschaftsideal gewidmet. S. beginnt mit den modernen Interpretationen und Kritiken Platons von Karl Popper, Leo Strauss und Friedrich Nietzsche und geht dann dazu über, Platons Utopismus zu verteidigen. Utopismus ist für ihn fester Teil jeder politischen Gesellschaft, die eine bestimmte Entwicklungsstufe erreicht hat, und er versteht darunter das Konzept einer Welt, die zwar herbeigesehnt wird, aber dennoch auf den Sorgen der Gegenwart beruht, wobei die Frage nach der Praktikabilität und Legitimität sekundär sind. Platon geht von den Realitäten seiner Zeit aus und verlegt seine Utopie nicht in eine primitive Vorzeit. Er erkennt, daß ein Entwurf für eine politische Gemeinschaft nur dann funktionieren kann, wenn er „takes due

PLATO, The electronic Journal of the International Plato Society, n 8, 2008.

http://gramata.univ-paris1.fr/Plato

(c) All rights of reproduction of any form reserved. 
account of human appetite and the forces of evil it unleashes within societies of a size and complexity typical of the civilized world“ (204). Er bespricht das Problem, das Kriege für die ideale Stadt darstellen, und ausführlich die ideale Stadt als organisches Ganzes. In diesem Kontext geht er auch auf die Frage: „Plato the feminist?" (227-234) ein.

Im 6. Kapitel, „Money and the Soul“ (250-281) analysiert S. Platons Einstellung zur Gier, v.a. zur Gier nach Geld und Besitz, in der Politeia. Platons Einsicht, daß Gier die primäre Triebkraft für Zerstörung darstellt, d.h. für Stasis im Inneren und Imperialismus nach Außen, steht in einer Tradition, die mit Hesiod und Solon beginnt und zu Platons Zeit in Tragödie und Komödie weit verbreitet war. Doch stellt S. fest: „Where Plato pushed the analysis of the desire ,to have more' far beyond any of his predecessors was in his exploration of its roots in the human psyche. His theory of the soul constitutes the key to the ethical and political theory worked out in the Republic." (252). Aus diesem Grund analysiert S. detailliert die Gefahr, die von Streben nach Geld für Platons Utopie ausgeht, auf das letztlich jedes andere Streben nach Vergnügen hinausläuft, und wie Platon dieser begegnen will.

Kapitel 7 trägt den Titel „Ideology“ (282-331). Aus Angst davor, daß sich die Gesellschaft aus gegenseitigem Haß und Egoismus selbst zerstört, entwirft Platon sein Gesellschaftsmodell. Sein idealer Staat wird durch viele Elemente zusammengehalten und gesichert, wie z.B. eine feste Hierarchie, gemeinsame Erziehung für die herrschende Klasse und anderes. Hinzu kommt aber auch Ideologie, was S. wie folgt versteht: „What I have in mind is ideology as a highly articulated system of widely and deeply held beliefs and cultural values that is strongly influential on behaviour." (282) Als Schlüsseltext interpretiert hier S. den Mythos von der edlen Lüge in Buch 3 der Politeia (414b-415d), der zum Zweck hat, die Bürger dazu zu bringen, „sich mehr um die Stadt und einander zu sorgen“" (415d). Wenn die Wächter ihre Aufgabe richtig erfüllen sollen, müssen sie die Stadt lieben. Die Lehre von den verschiedenen Metallen in der Seele ist die Grundvoraussetzung dafür, daß im Idealstaat kein Nepotismus auftritt und das eugenische Programm funktioniert. Interessanterweise, wie S. betont (286), schlägt Sokrates nicht vor, diese Einstellung durch rationale Argumentation oder mit Hilfe der Dialektik in Buch 7 zu bewirken. „It is something Plato evidently took to require not reason or argument, but the production of a generally

PLATO, The electronic Journal of the International Plato Society, n 8, 2008.

http://gramata.univ-paris1.fr/Plato

(c) All rights of reproduction of any form reserved. 
accepted ideology: accepted not just by the citizens at large, but by the rulers and military, too, and indeed principally by them" (286) Daß den Bürgern hier etwas grundsätzlich Falsches vermittelt wird, ist für Platon unproblematisch, da er keine grundsätzliche Abneigung gegen die Lüge vertritt.

In den Nomoi übernimmt die Religion die Funktion von Ideologie, was erklärt, daß sie in der dort präsentierten Gesellschafts- und politischen Theorie durchgehend zu finden ist.

Das Buch ist eine Herausforderung für den Leser. Es bietet, was es verspricht (VIII), eine Analyse von Platons politischer Philosophie in ihrem historischen Kontext, bezieht aber ebenso moderne politologische Ansätze mit ein. Wenige Leser werden in allen diesen Bereichen so kundig sein wie S. Wenngleich sich die Serie, in der es erschienen ist, an einen weiteren Leserkreis richtet, so werden es ebenso und vielleicht gerade Spezialisten aus den genannten Bereichen mit großem Gewinn lesen. Es ist eine Fundgrube an gelungenen Detailinterpretationen und globalen Einsichten. Da es sich durchgehend mit der neuesten und älteren englischsprachigen Literatur zum Thema auseinandersetzt, bildet es zudem einen idealen Ausgangspunkt für eine Beschäftigung mit Platon als politischem Denker.

Stefan Schorn

PLATO, The electronic Journal of the International Plato Society, n 8, 2008.

(c) All rights of reproduction of any form reserved. 